\title{
Rail Accessibility in Germany: Changing Regional Disparities between 1990 and 2020
}

\author{
Fabian Wenner (1), Alain Thierstein (1) \\ Received: 22 May 2020 - Accepted: 18 January 2021 - Published online: 26 February 2021
}

\begin{abstract}
Transport accessibility is an important location factor for households and firms. In the last few decades, technological and social developments have contributed to a reinvigorated role of passenger transport. However, rail accessibility is unevenly distributed in space. The introduction of high-speed rail has furthermore promoted a polarisation of accessibility between metropolises and peripheral areas in some European countries. In this paper we analyse the development of rail accessibility at the regional level in Germany between 1990 and 2020 for 266 functional city-regions. Our results show two different facets: the number of regions that are directly connected to one another has decreased, but at the same time the spatial disparities of accessibility have decreased, albeit to a small extent. This development was strongest in East Germany after German reunification and thus largely a consequence of the renovation of the conventional rail infrastructure, not high-speed rail. Nevertheless, it can be concluded that the introduction of high-speed traffic in Germany did not lead to an increase in accessibility disparities. Instead, the accessibility effects of high-speed rail in Germany seem to break the traditional dichotomy between core and periphery.
\end{abstract}

Keywords: Accessibility - Rail - High Speed Rail - Regional Disparities - Germany

Fabian Wenner, Lehrstuhl Raumentwicklung, Technische Universität München, Arcisstraße 21, 80333 München f.wenner@tum.de

Prof. Dr. Alain Thierstein, Lehrstuhl Raumentwicklung, Technische Universität München, Arcisstraße 21, 80333 München thierstein@tum.de

(c) (1) () () 2021 Wenner; licensee oekom verlag. This Open Access article is published under the Creative Commons Attribution-ShareAlike 4.0 International Licence.

\section{Erreichbarkeit im Schienenverkehr in Deutschland: Sich wandelnde regionale Disparitäten zwischen 1990 und 2020}

\section{Zusammenfassung}

Verkehrliche Erreichbarkeit stellt einen wichtigen Standortfaktor für Haushalte und Unternehmen dar. In den letzten Jahrzehnten haben technologische und soziale Entwicklungen zu einer neuen Attraktivität des Schienenpersonenverkehrs beigetragen. Die Erreichbarkeit über den Schienenverkehr fält jedoch räumlich sehr unterschiedlich aus. Die Einführung des Hochgeschwindigkeitsverkehrs hat zudem in einigen europäischen Ländern eine Polarisierung der Erreichbarkeit zwischen Metropolen und peripheren Räumen befördert. In diesem Beitrag analysieren wir die Entwicklung der Bahnerreichbarkeit auf regionaler Ebene in Deutschland zwischen 1990 und 2020 für 266 funktionale Stadtregionen. Unsere Ergebnisse zeigen zwei unterschiedliche Facetten: Die Zahl der direkt miteinander verbundenen Regionen hat sich verringert, aber zugleich zeigt sich für die Erreichbarkeit der Bevölkerung eine Abschwächung der räumlichen Disparitäten, wenn auch in geringem Maße. Diese Entwicklung war in Ostdeutschland nach der deutschen Wiedervereinigung am stärksten und damit weitgehend eine Folge der Sanierung der konventionellen Schieneninfrastruktur, nicht des Hochgeschwindigkeitsverkehrs. Dennoch kann der Schluss gezogen werden, dass seine Einführung in Deutschland nicht zur Erhöhung von Erreichbarkeitsdisparitäten geführt hat. Stattdessen scheinen die Erreichbarkeitswirkungen des Hochgeschwindigkeitsverkehrs in Deutschland die traditionelle Dichotomie zwischen Kern und Peripherie zu durchbrechen.

Schlüsselwörter: Erreichbarkeit - Bahn - Hochgeschwindigkeits-Bahnverkehr - regionale Disparitäten Deutschland 


\section{Introduction}

Accessibility is an important determinant of regional and local development (Clark 1958). Transport infrastructure and services expand the opportunities for households to access distant jobs and amenities, and support, inter alia, the emergence of agglomeration benefits for firms. Hence, accessible places and regions have long attracted economic activity (Axhausen 2008: 5).

After a phase of relative decline, passenger rail transport has experienced a resurgence as a transport mode in $\mathrm{Eu}-$ rope during recent decades. Several societal and technological developments have contributed to this reinvigoration. Tertiarisation and the rise of the knowledge economy have increased demand for face-to-face communication and business travel (Hall/Pain 2006: 7; Thierstein/Lüthi/Kruse et al. 2008). This has supported reurbanisation and a tendency towards polycentric development which involves the major metropolitan cores (Münter/Volgmann 2014) being increasingly organised in a global space of flows (Castells 1996). These processes are advantageous to passenger rail as a linear, mass-transport oriented form of transport, which furthermore often directly services inner-city areas and allows travel time to be used for work purposes. At the same time, rail infrastructure can reinforce this pattern towards "integrated corridor economies" (Blum/Haynes/Karlsson 1997: 1). Changing consumer preferences with regard to ecological concerns are also an advantage for rail as opposed to air and road travel due to its relatively low emissions (cf. Schwarzer/Treber 2013). Finally, there have been technological and managerial improvements, particularly in the form of high-speed rail which has greatly increased average speeds on some routes. This has improved the competitive advantage of passenger rail for many routes. Hence, passenger rail accessibility plays a growing role in locational decisions.

However, accessibility is unequally distributed in space, and the described developments have sometimes contributed to a widening of rail accessibility disparities between regions. Particularly, the introduction of highspeed rail has been discussed in scientific literature as promoting a polarisation of accessibility between metropolitan cores on the one hand and peripheral areas on the other, on a European scale and also within several European countries (Spiekermann/Wegener 1996). Its capital intensity and technical characteristics mean that high-speed rail is established first on routes between major metropolitan centres, while parallel, slower conventional services with more frequent stops are in some cases discontinued. At the same time, conversely, it has been argued that high-speed rail can serve cohesion goals when it links peripheral and central regions (Monzon/Lopez/Ortega 2019: 527). Likewise, re- cent decades have seen an increased profit orientation and the (partial) privatisation of several national rail providers throughout Europe with adverse consequences for regional accessibility in some countries, as peripheral and tangential lines often have the lowest internal profitability. On the other hand, progressing European integration has in some cases reduced the peripherality of border regions in the rail network.

Despite numerous (mostly ex-ante) studies in several European countries and for Europe as a whole, there have been few assessments of the development of rail accessibility in the case of Germany. During the last three decades, the rail network has been influenced by the triple effects of reunification, the de jure privatisation of the railway service provider, and the construction of more than $1,000 \mathrm{~km}$ of new high-speed rail infrastructure, which has reshuffled regional accessibility. Accessibility studies in countries with a monocentric urban structure and radial network development, such as France, Spain and the UK, have often found accessibility changes to be essentially a function of the reduction of travel time to the main metropolis. The polycentric spatial structure and dispersed network layout in Germany means that accessibility developments are expected to be less clear.

Furthermore, continuing digitalisation of previously analogous data means that new sources become available for use in research, such as historical timetables that allow an expost assessment of accessibility levels. The research presented by this paper exploits a novel source, a digitalised database of German long-distance rail timetables from 1987 until today.

The aim of the paper is to analyse and visualise the spatially differentiated development of rail accessibility among German regions during the last 30 years. We develop a monomodal rail accessibility model for 266 functional city-regions in Germany in 10-year intervals between 1990, the year prior to the introduction of high-speed rail in Germany, and 2020, using potential accessibility and degree centrality indicators. Our study links back to the considerable body of research on regional accessibility changes caused by European integration published during the 1990s, and re-examines their ex-ante projections and results against the background of longitudinal and current data gathered using novel methods and sources. The main research question is: Has the spatial distribution of passenger rail accessibility in Germany become more equitable during this time period?

The paper is structured as follows. In the subsequent second section, we briefly revisit previous rail accessibility analyses in Europe before we provide more detail of our case study in Section 3. The fourth section describes the methods and data used. In the fifth section, we present 
results before concluding with more general remarks and implications in the sixth section.

\section{Rail accessibility disparities and dynamics in Europe}

Rail accessibility changes can be analysed on different spatial scales, from the station surroundings to the regional (Mohino/Loukaitou-Sideris/Urena 2014) and national scales. This paper is focused on the regional scale, as we are interested in the effects of inter-regional infrastructure and service changes, even though accessibility changes on the local level can be substantial as well, particularly in the case of line closures, which merits a separate discussion. We hence conceptualise these regions as 'containers' which are uniformly affected by an accessibility change.

There is a rich literature on regional accessibility (including rail) on a European scale, starting with Keeble, Owens and Thompson (1982). ESPON (2015: 46-55) offers a comprehensive overview. Many of these studies date back to the 1990s, where the first phase of high-speed rail construction and the fall of the iron curtain triggered an initial wave of research, and are static. As it was still too early to measure accessibility effects, many of these studies are now outdated, or only present forecasts but no evaluation.

Regarding the general distribution of rail accessibility, most studies confirm the well-established 'blue banana' (Brunet 1989) pattern of an arch of high population density in north-western Europe with the highest accessibility of population (e.g. Poelman/Ackermans 2016). Results for multimodal accessibility similarly often find Paris and Frankfurt to be the centres of accessibility in Europe for longer trips, and for continental and global accessibility (BAK Basel Economics 2007: 16). Martín and Reggiani (2007: 558) estimate dynamics of rail accessibility and describe a shift in the centre of gravity within the EU from Paris eastwards in the decade between 2007 and 2020. Peripheral regions on the Iberian Peninsula are often identified as being least accessible by rail. However, there are also situations we call 'inner peripheries' and 'outer cores': some (mostly rural) regions that are geographically central within Europe are much less accessible than the agglomerations (Spiekermann/Neubauer 2002: 26). On the other hand, agglomerations, typically the capitals, in countries that are geographically peripheral within Europe can nevertheless exhibit a high level of rail accessibility (Lutter/Pütz/ Spangenberg 1993). Compared to road, rail accessibility is much more concentrated and discontinuous, but infrastructure investments can have a stronger influence on the distribution (Spiekermann/Wegener 2006: 16).

The dynamics of rail accessibility have been studied par- ticularly under the lenses of European integration and highspeed rail development. High-speed rail is commonly defined as newly built lines for speeds of $250 \mathrm{~km} / \mathrm{h}$ or more, and upgraded lines for at least $200 \mathrm{~km} / \mathrm{h}$ (European Council 1996); speeds in Europe reach $320 \mathrm{~km} / \mathrm{h}$. First developed in Japan with the Shinkansen in 1964, high-speed rail has been introduced in and between a number of European countries, including Italy (1977), France (1981), Germany (1991) and Spain (1992). International high-speed rail corridors within the EU only materialised at a late stage, mainly as part of the Trans-European Networks (TEN) programme, and essentially involved stitching together the national networks (Vickerman 1997: 22). Network length and ridership have since grown strongly ${ }^{1}$ and new lines continue to be proposed and built. Resulting travel time changes have been very dynamic and are typically more sudden and stronger than for other modes (Bruinsma/Rietveld 1998: 518; BAK Basel Economics 2007: 16). This is advantageous for scientific analysis, since the identification and association of effects becomes more difficult in situations with gradual changes.

High-speed rail networks were essentially developed nationally by the (state-owned) railway companies and vary e.g. with respect to network structure, intermodality and station placement, which can all have a decisive influence on accessibility outcomes. Monocentric and politically centralised countries typically exhibit a network structure more radially aligned to their capitals (cf. Albalate/Bel/Fageda 2012). Systems range from fully segregated separate highspeed rail infrastructure to full integration between conventional, high-speed rail and even freight traffic (Campos/de Rus 2009). Integrated systems are typically more expensive, but allow a better trickling-down of accessibility effects. There are also differences regarding station placement and service provision. While the capital intensity and technical characteristics of high-speed rail typically mean that it is first implemented between major centres over the shortest possible distance, some lines include (out-of-town) stations in peripheral and rural areas that happen to be located on such axes, greatly increasing their accessibility. On the other hand, there is the risk of a reduction of accessibility, particularly for smaller regional centres, if conventional rail services are discontinued after the opening of parallel highspeed rail lines (Bruinsma/Rietveld 1993: 934; Vickerman 1997: 26).

Spain now has the longest high-speed rail network in the world after China, both of which have attracted substantial academic interest (e.g. Cao/Liu/Wang et al. 2013;

\footnotetext{
1 http:// www.uic.org/spip.php?action=telecharger\&arg=102 (15.12.2020).
} 
Monzon/Lopez/Ortega 2019; Ribalaygua/Perez-Del-Caño 2019). The scientific debate on the question of whether high-speed rail increases or decreases accessibility disparities between regions has been inconclusive. On the one hand, several studies associate high-speed rail with an increasing 'polarisation' of accessibility and hence economic discrepancies or at least new layers of advantages and disadvantages on a European (Spiekermann/Wegener 1996: 38) and national scale (Plassard 1994: 61). High construction and running costs mean that high-speed rail is usually first implemented between the most populous and economically dynamic regions, improving their connections and mutual accessibility, but not that of the area in between ('tunnel effect'). Such an increasing disparity is not necessarily accompanied by lower absolute accessibility levels in remote regions. Transport infrastructure and services in remote regions can be unchanged, or even slightly improved and their absolute accessibility levels increased, but in relative terms their accessibility decreases compared to the central regions where accessibility gains are even higher (Schliebe 1983; Spiekermann/Wegener 1996); Hall (2009: 65) called this the "peripheralization of the periphery".

On the other hand, several authors highlight the balancing effect of high-speed rail. Using average travel times to a number of chief economic activity centres weighted by GDP, Gutiérrez, González and Gómez (1996) find that the greatest increases in relative accessibility within the EU can be registered in regions in which (foreseeably) the stations of the future network will be located, but the greatest accessibility increases in absolute terms correspond to the peripheral regions. They highlight that high-speed rail also has an important symbolic dimension for cohesion. Lutter and Pütz (1993) assume strong changes of regional attractiveness through high-speed rail, particularly for peripheral regions with an existing economic base, and plead for a $\mathrm{Eu}-$ ropean transport policy that seeks homogenous infrastructure provision across regions. Several more recent studies on a national level have likewise found beneficial effects of high-speed rail for the evenness of accessibility (Gutierrez 2001; Monzon/Lopez/Ortega 2019). Nevertheless, the economic effects even of an accessibility increase for peripheral regions are contested, a "straw effect" could mean that they lose economic activity to the core regions (Ottaviano 2008: 19). In any case, such effects are contextspecific and far from automatic (Chen/Hall 2011). Many authors highlight that for high-speed rail to reduce regional disparities, mixed-mode services combining high-speed and conventional stretches and intermodality at high-speed rail stations are important for spreading accessibility benefits to a wider area (Vickerman 1997: 32; Martínez SánchezMateos/Givoni 2012; Chen/Hall 2013).

The review shows that there is a need for more analy- ses on the dynamics of accessibility disparities. Many of the recent studies specifically treat a selected single line, while systematic studies across cases are rare. Several authors call for greater attention to be paid to comparative, quantitative accessibility analyses over a longer time frame (Levinson/Wu 2020: 149) and between different states of networks (Axhausen 2008: 20; BBSR 2019: 103), and demand continuous accessibility modelling (Stępniak/Rosik 2018: 309).

\section{Case Study: Germany}

The development of railway infrastructure and services in Germany has been characterised by three broad trends during recent decades: high-speed rail construction, privatisation and the aftermath of German reunification.

The construction of several new high-speed rail lines in West Germany started in the 1970s, after a long phase of little investment in rail infrastructure. The conventional rail network in Germany was considered outmoded and unfit fur purpose (Schliebe 1983), also because the traditionally strong east-west routes were severed. Construction followed a demand-driven rationale, mostly in north-south orientation, as despite the strong growth of car and lorry traffic some lines were operating at their capacity limit (Schliebe/ Würdemann 1990: 227-229). In contrast to other European countries, the new lines were designed for freight train use as well, to connect the southern industrial regions with the harbours in the north. This required gentler slopes and hence expensive tunnelling and bridging in the hilly terrain of central Germany, which significantly increased costs and landscape encroachment (Jänsch 1991: 367). Planners also aimed for interoperability between conventional and highspeed rail, i.e. high-speed trains also use conventional lines, and conventional intercity trains and even regional trains use stretches of the high-speed network, a "fully mixed" network mode (Campos/de Rus 2009: 20-21). After the opening of the first high-speed rail line in Germany between Hannover and Würzburg in 1991, the 'Inter-City Express' (ICE) brand was introduced for high-speed trains. The ICE soon reached the expected passenger volumes and profitability (Jänsch 1991). To date, seven high-speed rail lines covering $1260 \mathrm{~km}$ have been completed.

The privatisation of railways has had an effect on rail services in recent decades throughout Europe. The UK went furthest with the full privatisation of rail operations in 1994, including the network infrastructure. Other European countries re-organised and sometimes semi-privatised their mostly still national rail companies, initiated by EU legislation on equal access to infrastructure networks and a reform of the subsidy regime for transport provision. In general, 
many of the still national, integrated companies were separated into a network and a service operation company, and often further subdivided into freight and passenger rail. The German state railway company Deutsche Bundesbahn was transformed into a private enterprise (Deutsche Bahn, DB) in 1994, but with $100 \%$ of the shares in public ownership. Successive governments aimed for a (part-)divestment, but the plan was ultimately dropped in the 2008 financial crisis. Together with EU laws on public transport subsidies, the reorganisation meant the concentration of DB on profitable long-distance lines, while (inter)regional services were discontinued or left to be subsidised and competitively tendered by the federal states.

A special circumstance in the German case is the reunification of its eastern and western parts in 1990. Many connections across the inner-German border, particularly local lines, had been severed since the establishment of the two German states and were subsequently re-established in the years after 1990. The two separate railway companies were merged. In addition, a set of large-scale transport infrastructure projects, the "German Unification Transport Projects" (Verkehrsprojekte Deutsche Einheit, VDE) were set up to reconnect east and west and improve transport infrastructure in East Germany. They included nine rail projects, among them two new high-speed rail lines, at an investment volume of approximately 15 bn euros (Holzhauser/Steinbach 2000: 129).

Recently, there have been calls for Deutsche Bahn to refocus on its role as a domestic supply-oriented public service provider, rather than a profit-oriented internationally operating firm, particularly to be able to implement climate protection targets. Following the example of the Netherlands and Switzerland, rail policy is also increasingly oriented towards optimising seamless interchanges and adapting infrastructure to the desired 'integrated timetable', rather than vice versa. The most recent Federal Transport Infrastructure Plan (Bundesverkehrswegeplan) with a time horizon of 2030 allocates about $40 \%$ of new investment in transport infrastructure to rail projects and contains eight new passenger high-speed lines for $250 \mathrm{~km} / \mathrm{h}$ or more, including those necessary for integrated timetables, the so-called Deutschland-Takt (BMVI 2016: 41). ${ }^{2}$

There have been few studies specifically on regional rail accessibility in Germany. Evangelinos, Hesse and Püschel (2011) calculated a combined rail accessibility indicator for Germany consisting of gravitational accessibility of economic output, daily accessibility of population within four hours and relative network efficiency. The research found

\footnotetext{
2 Also see https://www.bmvi.de/SharedDocs/DE/Artikel/E/
} zukunftsbuendnis-schiene.html (15.12.2020). that Frankfurt by far dominates the ranking, before Düsseldorf, Hannover and Köln; Trier being last. Regarding accessibility dynamics, Steinbach and Zumkeller (1992) projected that high-speed rail expansion would lead to the creation of a continuous zone of equally high rail accessibility throughout south-west Germany. Schliebe and Würdemann (1990: 233) estimated an average rail travel time reduction between German regions of 45 minutes between 1990 and 2000. Using a contour-based travel time model without distance decay, they estimated that a high number of region pairs would fall within the critical four-hour threshold for daily return business trips. Beneficiaries were particularly the (then capital) city of Bonn, and the West in general, while they were pessimistic for Berlin. This study did not take into account the VDE projects. Holzhauser and Steinbach (2000) closed this gap and simulated the accessibility effects of the post-reunification transport projects, concluding that the economic cores of eastern Germany (particularly Saxony, Saxony-Anhalt and Thuringia) would profit most, thereby balancing accessibility across the country's regions. In addition, they highlighted that Berlin would be released from its peripheral position.

\section{Methods}

The aim of the empirical part of this paper is to estimate rail accessibility for business trips in Germany on a regional scale between 1990, the year before the opening of the first high-speed rail line, and today. Despite their often positive and significant relationships, "macro-level models" (Berechman 1995: 22), which use some measure of the capital stock (e.g. km of road) as an explanatory variable, fail to account for the fact that transport infrastructure investments are not made in isolation. The alignment and position in the network of such investments provide a vital context for their effects (Banister/Berechman 2001: 210; Axhausen/Fröhlich/ Tschopp 2006: 3). Accessibility measures, which consider the actual services provided by infrastructure networks, are thus preferable.

Accessibility can be defined as the "potential for opportunities of interaction" (Hansen 1959: 73) of a territory or place and can be measured in various ways. Detailed overviews of the operationalisation of accessibility can be found in Song (1996), Geurs and van Wee (2004) and Levinson and $\mathrm{Wu}$ (2020). In this paper, we mainly use two accessibility measures: potential accessibility using an exponential decay function, and degree centrality. Each specific accessibility indicator captures only some dimensions of the accessibility concept; hence, it is useful to combine several subindicators (Martín/Reggiani 2007: 555). Potential accessibility shows the advantages that a rail connection provides 
in terms of proximate contact partners within a typical daily return travel journey, while degree centrality emphasises direct connectedness without changeovers, with no distance decay.

\subsection{Potential Accessibility}

Some studies of high-speed rail use before/after travel times to one specific selected population centre as a proxy for accessibility change (e.g. Martínez Sánchez-Mateos/Givoni 2009 to London in the case of the UK). This might be a permissible approximation in monocentric settings, but it cannot be applied in the German case. For polycentric situations, potential-based measures are more useful. Potential accessibility measures are calculated by summing up the number of destinations that can be reached from a point in a network, each weighted by its attractiveness (e.g. economic mass or population), and inversely weighted by distance. They rest on the assumption that the likelihood for personal interactions, and consequently travel, from location $i$ to a certain destination $j$ depends on the number of opportunities the destination presents, and the difficulty to reach it (Barthélemy 2011: 35). Potential measures have been widely used in human geography and transport studies and represent an adequate way to measure the benefits of transport projects, since they do not depend on assumptions concerning user benefits and include (wider) societal benefits (Beria/Debernardi/Ferrara 2017: 68). As the opportunity component of our analysis, we use population, since it represents an easily available and neutral indicator, compared to alternative destination weights such as GDP. Population size of a destination region represents the number of potential business contacts that can be reached there. To measure distance, we use travel time.

Different types of functions can be used to model the distance decay. Exponential functions - also called gravitational functions - are most often used and generally considered most suitable (Song 1996: 479) since they are closely tied to travel behaviour theory (Handy/Niemeier 1997: 1177; Geurs/van Wee 2004: 133) and match empirical observations well. For our study, we use an exponential decay function in the form of eq. 1 ,

$$
P[i]=\sum_{j \in G-\{i\}} \frac{W[j]}{e^{\beta \cdot d[i, j]}}
$$

where $\mathrm{P}[\mathrm{i}]$ is the potential accessibility of location $\mathrm{i}, \mathrm{W}[\mathrm{j}]$ the weight of destination $j, d[i, j]$ is the travel time between locations $i$ and $j$, and $\beta$ is the exponent for adjusting the distance decay.

The decay factor is scale-dependent and hence must be adjusted for each case study depending on the travel purpose and the demand characteristics, based on observed data or comparative cases from the literature (Frost/Spence 1995: 1834; Geertman/Ritsema van Eck 1995: 70; Geurs/van Wee 2004: 133). Higher values mean a stronger distance decay and are hence suitable for short-distance interactions with greater emphasis on the land use component. The necessity for consistent data across all timescales limits the spatial resolution of our analysis to the (inter)regional scale, which is adequate for business-purpose daily return trips. A wide variety of decay factors is used in the literature, an overview can be found in Rosik, Stępniak and Komornicki (2015: 140). Studies with a similar approach have used decay factors in a very wide range, from 0.5 (Poelman/ Ackermans 2016), 0.2 (Axhausen/Fröhlich/Tschopp 2006) to 0.0051 (BAK Basel Economics 2007: 44) which represent a halving of the weighting after 1.3, 3.45 and 135 minutes, respectively. For this study, we follow the principle described by Östh, Reggiani and Galiazzo (2014) that the distance decay parameter should be fitted so as to match the halving of the weighting to the median travel time typical for the travel purpose under consideration. A range of international studies set the median travel time for business daily return trips at about two hours (e.g. Andersson/Karlsson 2004: 293; BAK Basel Economics 2007: 44 for meetings and trade fairs; Rosik/Stępniak/Komornicki 2015: 140 for 'international' trips). Recent statistical data for Germany on this issue is unavailable, but in line with these studies a decay factor of 0.0057 can be deduced from the distancebased values in Harrer and Scherr (2013: 65), assuming an average speed of $90 \mathrm{~km} / \mathrm{h}$ and omitting very short-range trips.

A challenge of the potential indicator lies in its interpretability and communicability, as the resulting values are dimensionless and meaningful only in reference to other values, and hence should be normalised to make sense (Geurs/van Wee 2004: 134). Its value lies especially in comparisons over time, not in absolute terms. We hence normalise all values to the highest value in 2020 as 100 . Particular attention must also be paid to the zone-internal travel time at the origin location, which is known as the 'self-potential' problem (Geertman/Ritsema van Eck 1995: 71; Bruinsma/Rietveld 1998: 503). Using the undiscounted mass of the origin would lead to an overestimation of the local mass. As an approximation, Frost and Spence (1995: 1835) suggest applying the distance decay factor to 0.33 times the radius of the origin area. For this paper, we follow the more precise method of Stępniak and Jacobs-Crisioni (2017) and calculate for each region the average weighted air-distance to the main station from each point of the $1 \times 1$ 
$\mathrm{km}$ GHSL population $\operatorname{grid}^{3}$ for the last available year before each analysis year to correct for differing internal population distributions, for which the distance decay is applied as well. Lastly, the network boundaries must be chosen in a way that is relevant to the research question to avoid an underestimation of accessibility in border regions. We hence include a buffer zone of four hours travel in our analysis and do not apply a border penalty, since all neighbouring countries are now part of the Schengen zone and rail travel is mostly frictionless.

\subsection{Degree centrality}

Rather than the number of potential contacts that can be reached at a certain cost being decisive for the attractiveness of a region, it might be that the number of destinations that can be reached directly from a certain origin, regardless of the travel time required, is more important. For example, Florida (2017) highlights the importance for a city's economic development of the number of destinations that can be reached with a direct flight. Likewise, local stakeholders in the German case have argued that direct rail connections to important urban centres are preferable to short travel times that require changeovers (e.g. Seydack 2015). Changeovers induce uncertainty in a travel chain and pose a disadvantage particularly for occasional users. As a second accessibility measure, we hence determine the number of other regional centres that can be reached directly without changing trains from a regional centre. In graph theory, this measure is one of the most basic features of a graph and is called 'degree' (Barthélemy 2011: 6) or degree centrality. It was defined by Freeman (1979) and is based on the idea that important nodes have the largest number of adjacent nodes (Erath/Löchl/Axhausen 2009: 383). In spatial networks, it is usually limited by geography, but this applies to a lesser extent to rail services, which can use several successive physical lines. The analysis of degree centrality is limited to the German rail network without the buffer zone. Mathematically, degree centrality can be formulated as:

$$
D[i]=\sum_{j \in G-\{i\}} A_{i j}
$$

where $\mathrm{D}[\mathrm{i}]$ is the degree centrality of location $\mathrm{i}$, and Aij is defined as 1 if $i$ and $j$ are connected, 0 otherwise.

Our analysis covers four points in time: 1990, 2000, 2010 and 2020. We use dynamic population values as an 'opportunity' measure, which gives a more realistic impression of

\footnotetext{
3 Global Human Settlement; see https://ghsl.jrc.ec.europa.eu/ download.php?ds=pop (15.12.2020).
}

regional accessibility development, particularly given the long timespan of the analysis and the strong population shifts especially in eastern German regions since 1990. However, we perform an alternative calculation with constant population to isolate the effects of transport infrastructure changes on accessibility as opposed to population effects (cf. Stępniak/Rosik 2018). The dynamic population data used during the study period means that accessibility changes can be caused by both shorter travel times and changing population size. We hence calculate an alternative scenario with the rail network of 1990 but the population distribution of 2020, and subtract it from the actual calculation. The result allows the different factors influencing the accessibility growth to be discerned (cf. Condeço-Melhorado/Zofío/Christidis 2017).

\subsection{Limitations of accessibility models}

All accessibility indicators used here suffer from a number of limitations. First, the accessibility value of one node is attributed to the whole region. This generalisation can produce unrealistic results, as some parts of the region might be less accessible than the main city (Gutiérrez/ González/Gómez 1996: 237). Using homogenous functionally defined regions can mitigate this shortcoming to a certain degree. Consequently, this means that inner-regional accessibility changes, e.g. through the closure of smaller local rail lines, are not covered by the analysis. However, such closures were widespread in the 1990s and 2000s, particularly in eastern Germany, and might have led to drastic accessibility losses on a finer scale. The meaningfulness of the model hence always depends on the adequate choice of nodes and zones (Bruinsma/Rietveld 1998: 502). Second, frequencies of connections are only implicitly included in the model, while in practice this can be a main determinant of the attractiveness of a train connection. A greater consideration of frequency would require additional assumptions on the time-value of certain frequency thresholds or more complicated agent-based models, which is why we abstain from it for this study, but we see it as having important potential to improve the model further. Data limitations in our case also prevent a more accurate modelling of changeover times, which would be desirable. Third, we use the same functional urban areas based on 2015 data for all analysis years, even though functional spatial relations were not the same in 1990, particularly along the former inner-German border. In addition, changing rail accessibility itself might have altered the delineation of some of the functional areas. This represents a methodological blur that we accept in order to avoid other, potentially more grave distortions induced by changing spatial units. Last, the dataset 
is timetable-based, i.e. does not consider delays, which we assume to occur evenly across the network.

\subsection{Datasets}

The spatial base units of our analyses are 266 functional city-regions ("Stadt-Land-Regionen") developed by the German Federal Institute for Research on Building, Urban Affairs and Spatial Development. ${ }^{4}$ They are homogenous, continuous, non-overlapping areas free of exclaves, based on the functional interlocking between urban cores and their hinterlands. This avoids difficulties arising from the heterogeneous definition of administrative areas even of the same hierarchical level between the German federal states. In the four-hour buffer zone, we use an additional 209 NUTS-3 ar$e^{e} s^{5}$ as an approximation of functional urban areas, which are of a similar spatial extent.

We use four rail network datasets of Germany for the years 1990, 2000, 2010 and 2020. The year 1990 was chosen as base year since it represents the situation before the opening of the first high-speed rail line in Germany (1991). Ten-year intervals provide a balance between data economy and detail of results. For each functional city region in Germany and each NUTS-3 region in the four-hour buffer zone, a main station was defined based on the highest number of departures per day, or, where this was ambiguous, based on centrality and importance in the local context. All regions were served by rail in all analysis years, however in some cases the main station changed over time (e.g. Potsdam, Jena).

The dataset contains the fastest travel times of all regular train connections between the main stations, based on historical and current timetable data. The data was obtained from multiple sources, historical printed versions as well as current official online timetables and digitalised historical timetables. ${ }^{6}$ Accuracy of the sources was tested by comparing a set of randomly selected records with the printed timetable.

A connection is considered 'regular' if it runs at least once every two hours over a period of eight consecutive

\footnotetext{
4 https://www.bbsr.bund.de/BBSR/DE/forschung/ raumbeobachtung/Raumabgrenzungen/deutschland/regionen/ StadtLandRegionen/StadtLandRegionen.html?nn=2544954 (16.12.2020).

5 https://ec.europa.eu/eurostat/web/nuts/nuts-maps (16.12.2020) (2016 classification).

${ }^{6}$ https://www.fernbahn.de/datenbank/suche/\#form2 (16.12.2020). Fully digitalised and searchable historical timetables, like the one supplied by Markus Grahnert, are often provided on the private initiative of railway enthusiasts and constitute a novel and promising source for spatial research into the development of accessibility.
}

hours on a working day. In very few cases connections with a lower frequency than 120 minutes were included, if otherwise a region would be unconnected. If the fastest connection between two main stations required an interchange at a station not included in the dataset, this station was added to the dataset but received no weight. This resulted in a network of 622 nodes and 984 edges in 1990, growing to 817 nodes and 1350 edges in 2020 . For interchanges at stations, a changing time of two minutes was assumed, since the introduction of integrated fixed-interval timetables mean that connections are often seamless and timed. The resulting data can be accessed in a digital repository (Wenner/Thierstein 2020a).

\section{Results}

This section describes our findings. It is structured as follows. First, we show the distribution of accessibility by region separately for the different points in time 1990, 2000, 2010 and 2020, respectively. Next, we visualise the changes of accessibility during this period. Finally, we present results on the question of whether the changes amount to an increase or decrease in regional accessibility disparities.

\subsection{Regional Accessibility Distribution}

Figures 1, 2, 3 and 4 show the accessibility of population in terms of business trips by rail (potential accessibility, choropleth colours) and the number of other regions that can be reached without changing train (degree centrality, point symbols) for regions in Germany for the years 1990, 2000, 2010 and 2020 . The accessibility values are normalised on the highest value in 2020, Köln as 100 . Relatively high accessibility values close to a border are due to the inclusion of the four-hour buffer zone in the calculation that was omitted for the visualisation.

The figures show a clear general trend of overall rising potential accessibility while at the same time the general spatial distribution of accessibility is largely preserved. The most accessible regions by rail are those of the western arc along the Rhein and the Rhein-Ruhr area throughout the study period. The accessibility distributions loosely resemble a smoothed-out population density map, suggesting a relatively evenly developed railway network, albeit with some deviations along the main rail corridors between the Rhein-Ruhr area and Berlin, and along the north-south corridor between Hannover and Frankfurt. The clear distinction of the former inner-German border vanishes after the first decade. The capital Berlin, as well as the second and third largest cities in Germany, Hamburg and München - all rather monocentric in spatial structure - exhibit only 


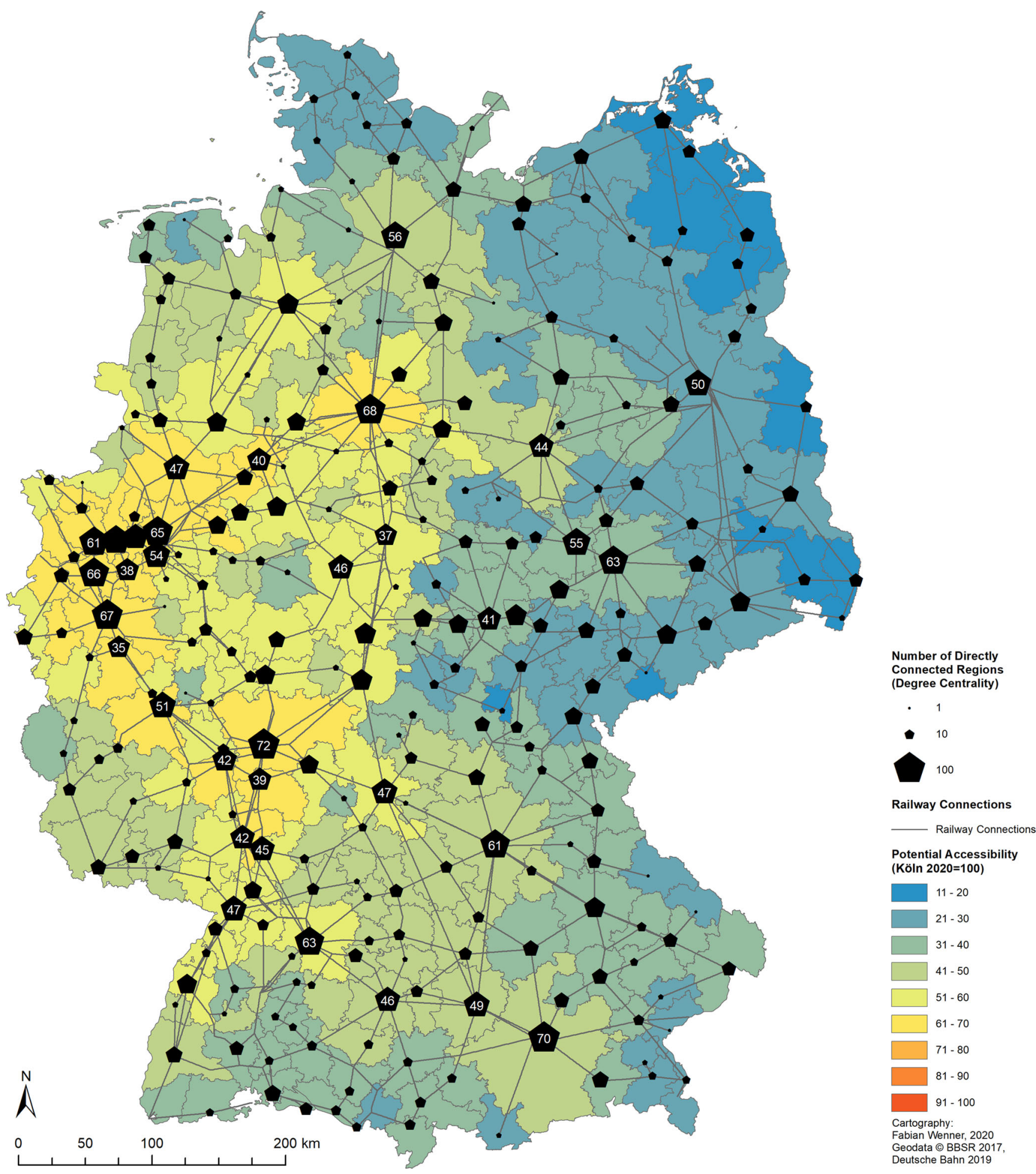

Figure 1 Regional Rail Accessibility and Degree Centrality in Germany in 1990

upper-medium accessibility values. Köln is rather the region with the highest rail accessibility throughout the study period, while Frankfurt main station constantly shows the highest degree centrality. Both cities are located in poly- centric regions, but are also more centrally located with respect to the other metropolitan areas in the country. The results hence confirm the previous study by BAK Basel Economics (2007: 19). Nevertheless, the figures also show the 


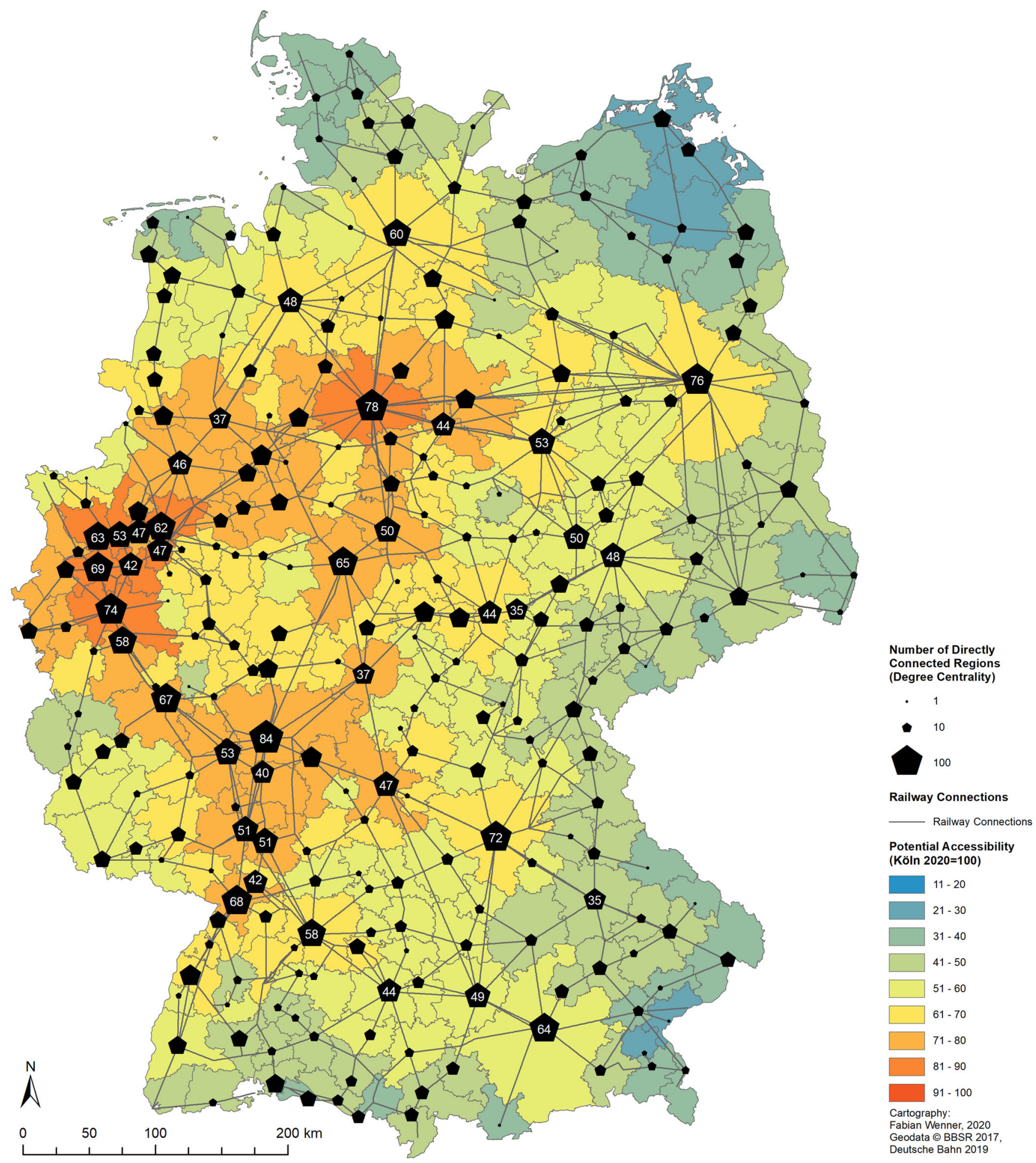

Figure 2 Regional Rail Accessibility and Degree Centrality in Germany in 2000

existence of inner and outer peripheries with respect to rail accessibility. Whereas the western-most regions are part of a continuous urbanised zone in the core of Europe that is well-linked by rail, regions along the northern and eastern borders show low accessibility values despite the inclusion of a buffer zone, indicating poor rail integration and low population potential. 

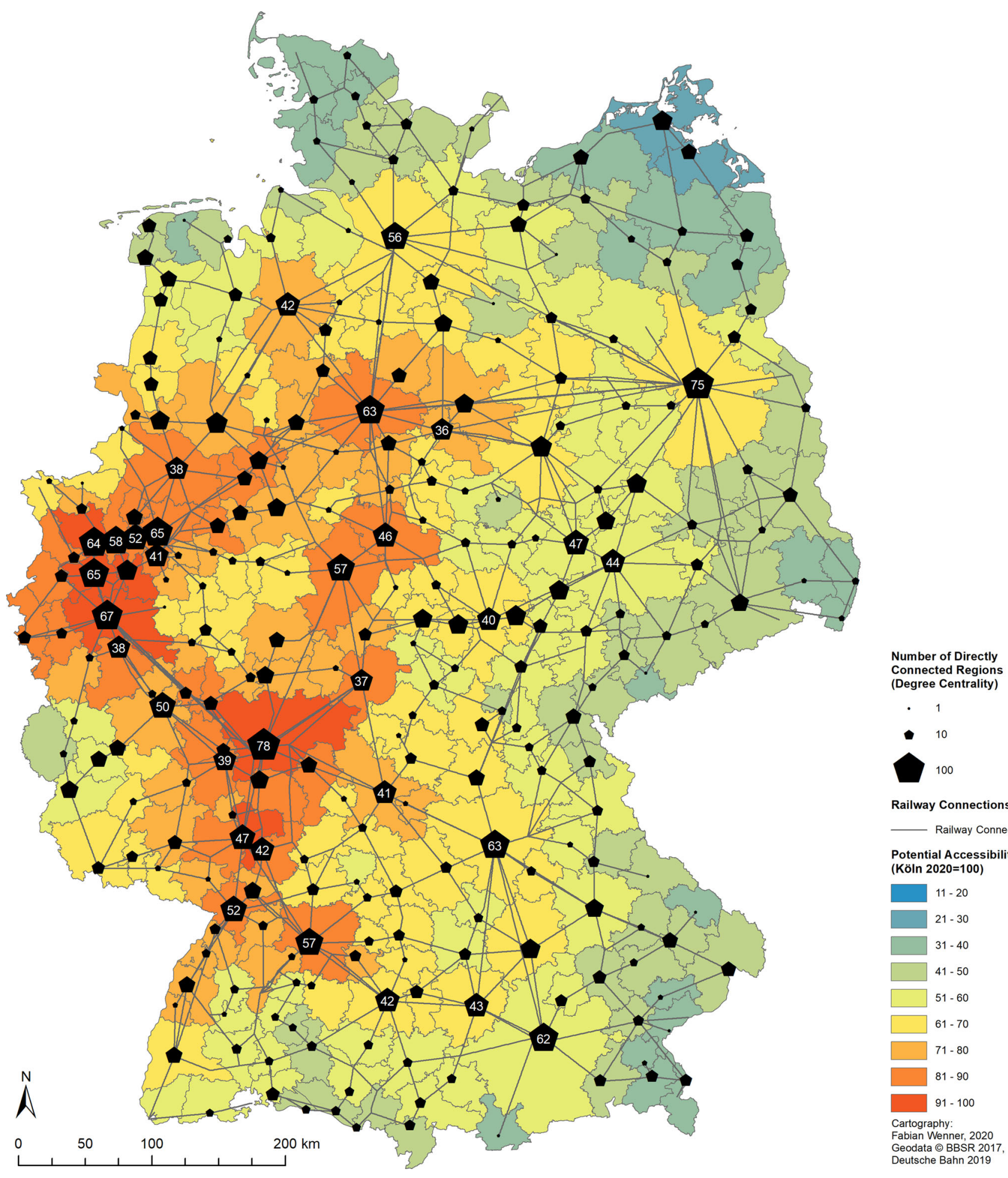

Railway Connections

Railway Connections

Potential Accessibility (Köln 2020=100)

$11-20$

$21-30$

$31-40$

$41-50$

$51-60$

$61-70$

ए $71-80$

$81-90$

$91-100$

Cartography:

Fabian Wenner, 2020 Geodata (c) BBSR 2017

Figure 3 Regional Rail Accessibility and Degree Centrality in Germany in 2010

Table 1 shows the ten most and least accessible regions by rail in Germany in 1990 and 2020 by potential accessibility of population. The shift of the gravitational centre towards the south becomes clear: Frankfurt, Mannheim and
Ludwigshafen are now in the top ten, while the post-industrial cities of Duisburg, Essen and Wuppertal have moved downward. Cities that have reoriented towards services like Köln and Düsseldorf remain high on the list. These changes 


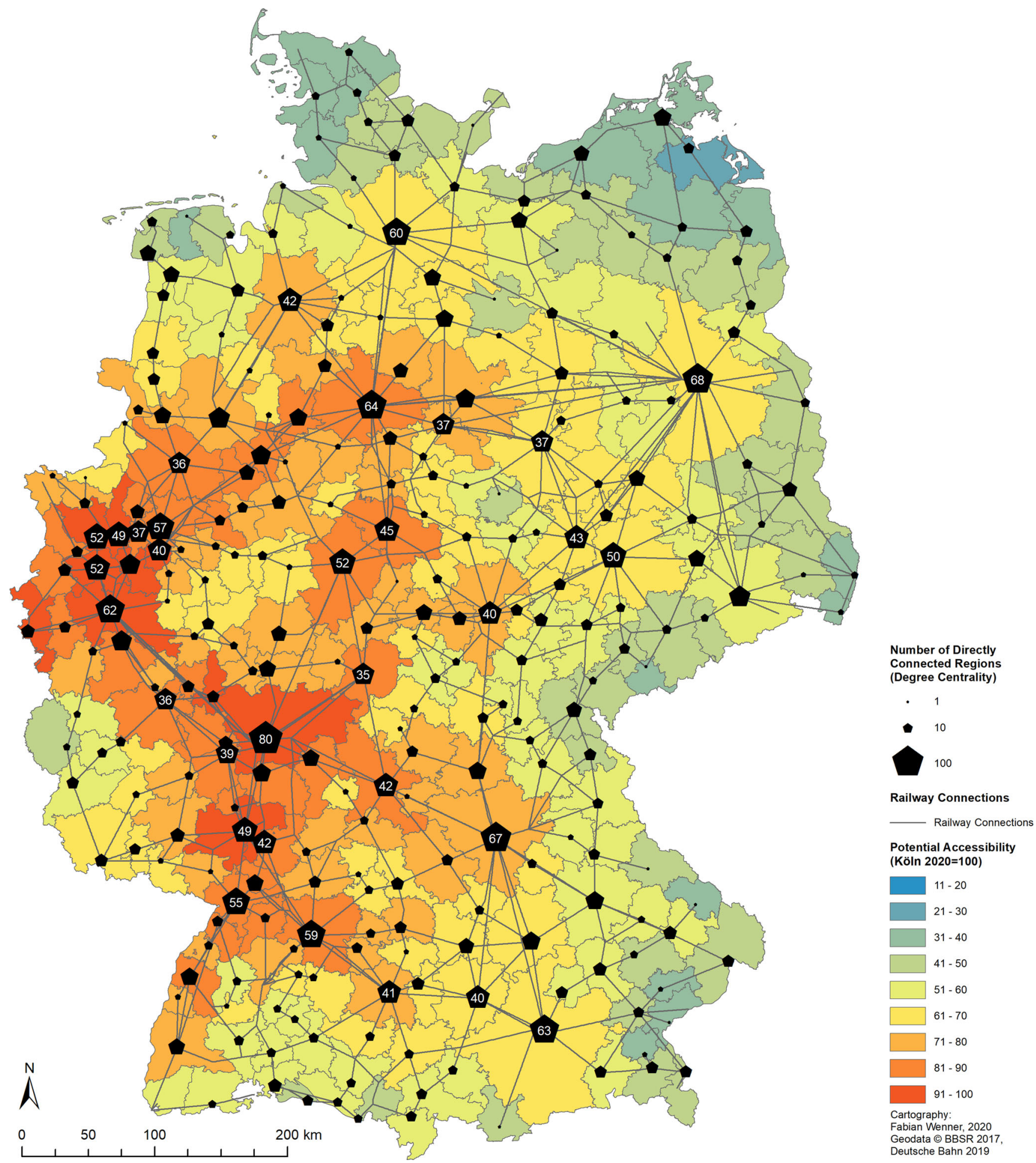

Figure 4 Regional Rail Accessibility and Degree Centrality in Germany in 2020 (Source: Wenner/Thierstein 2020b: 66)

are clearly induced by the new high-speed rail lines between Köln and Frankfurt and between Aachen and Brussels, also signified by the appearance of Limburg and Aachen on the list. The alignment and location of new high-speed rail lines in recent decades, together with a population shift, has strengthened the south of Germany in relation to rail access. The lower end of the list has changed from an alleastern composition to a mixed one in 2020. The regions 
Table 1 The ten most and least accessible regions by rail in Germany in 1990 and 2020 (Accessibility Index: Köln 2020 = 100)

\begin{tabular}{|c|c|c|c|c|c|c|c|c|c|}
\hline \multirow[b]{2}{*}{ Nr. } & \multicolumn{2}{|l|}{1990} & \multicolumn{2}{|l|}{2020} & \multirow[b]{2}{*}{$\mathrm{Nr}$} & \multicolumn{2}{|l|}{1990} & \multicolumn{2}{|l|}{2020} \\
\hline & Region & $\begin{array}{l}\text { Acc. } \\
\text { Index }\end{array}$ & Region & $\begin{array}{l}\text { Acc. } \\
\text { Index }\end{array}$ & & Region & $\begin{array}{l}\text { Acc. } \\
\text { Index }\end{array}$ & Region & $\begin{array}{l}\text { Acc. } \\
\text { Index }\end{array}$ \\
\hline 1 & Köln & 69.28 & Köln & 100 & 257 & Senftenberg & 19.80 & Aurich & 37.25 \\
\hline 2 & Duisburg & 69.22 & $\begin{array}{l}\text { Frankfurt } \\
\text { a.M. }\end{array}$ & 97.29 & 258 & Aue & 18.94 & Aue & 36.98 \\
\hline 3 & Düsseldorf & 68.90 & Düsseldorf & 96.15 & 259 & Prenzlau & 18.78 & Eggenfelden & 36.92 \\
\hline 4 & Essen & 68.00 & Mannheim & 95.14 & 260 & Stralsund & 17.88 & $\begin{array}{l}\text { Torgelow-Ferdi- } \\
\text { nandshof }\end{array}$ & 36.68 \\
\hline 5 & Wuppertal & 67.74 & Duisburg & 94.52 & 261 & $\begin{array}{l}\text { Torgelow-Ferdi- } \\
\text { nandshof }\end{array}$ & 17.41 & Burghausen & 36.10 \\
\hline 6 & Dortmund & 67.19 & Wuppertal & 93.92 & 262 & Bautzen & 17.37 & Husum & 33.36 \\
\hline 7 & Hagen & 66.84 & Ludwigshafen & 92.04 & 263 & Greifswald & 16.95 & Zittau & 32.81 \\
\hline 8 & Krefeld & 66.71 & Aachen & 91.74 & 264 & Görlitz & 14.67 & Flensburg & 31.90 \\
\hline 9 & Bochum & 66.41 & Essen & 91.59 & 265 & Sonneberg & 13.52 & Stralsund & 30.17 \\
\hline 10 & Bonn & 66.21 & Limburg & 90.71 & 266 & Zittau & 11.04 & Greifswald & 28.78 \\
\hline
\end{tabular}

are peripheral not only with regard to the rail system, but also geographically.

\subsection{Dynamics of Accessibility}

Figure 5 shows the cumulative relative accessibility changes for the 1990-2020 period as well as the new high-speed rail lines opened during this time with their opening years. Italic labels are placed in the regions with the highest and lowest potential accessibility gains in this period, ranging from $+285 \%$ (Sonneberg) to $+19 \%$ (Kleve). Rail accessibility changes in Germany in recent decades seem to have transcended the classical core-periphery dichotomy, showing rather a macro-regional pattern.

In total, four influences on rail accessibility changes can be identified (for some regions, more than one characteristic applies):

- A general area-wide positive effect on accessibility of the renovation of rundown conventional rail infrastructure in eastern Germany after reunification in 1990 (strongest in the first decade). This effect largely overshadows the other effects.

- Particularly strong relative increases of accessibility in formerly peripheral regions along the inner-German border, especially in eastern Germany (e.g. Sonneberg, Meiningen, Salzwedel and Wernigerode) due to the reestablishment of dismantled cross-border lines.

- Significant gains of both relative accessibility and direct connections in regions on domestic and international high-speed rail lines (e.g. Aachen, Ingolstadt, Kassel, Wolfsburg) are particularly strong in less populous regions coincidentally located along new lines (e.g. Limburg, Montabaur). Positive accessibility effects expand farther in a funnel-shaped pattern beyond the ends of new high-speed rail lines while flanking regions usually do not profit. By-passed regions lose direct connections but not accessibility, as more people can now be reached in the same time, albeit with a necessary changeover (e.g. Bad Hersfeld/Bebra, Jena, Koblenz, Magdeburg and Naumburg). This is linked to the advantages of the integrated implementation of high-speed rail in Germany with mixed conventional/high-speed rail traffic and frequent interchanges.

- Reductions in the number of directly connected regions, as a result of the rationalisation and reorientation of rail services on the most profitable inter-metropolitan routes in the wake of DB's privatisation. This meant a reduction of slower but direct long-distance connections along less populated corridors such as the central east-west connection Halle-Kassel-Rhein/Ruhr area and the corridor along the eastern border Dresden-Hof-RegensburgMünchen, along with the re-emergence of the capital Berlin as the leading eastern hub. The number of people living in regions directly served by long-distance rail has consequently decreased (1990: 61.3m, 2020: 56.6m).

Regions that were affected by neither of these influences show a stagnation of accessibility, particularly those in some west-German 'inner peripheries' with respect to the rail network (e.g. Bitburg, Oldenburg and Siegen). No region experienced a decline in accessibility, even though several regional cross-border lines with the Netherlands were closed during the study period despite accelerating EU integration. 


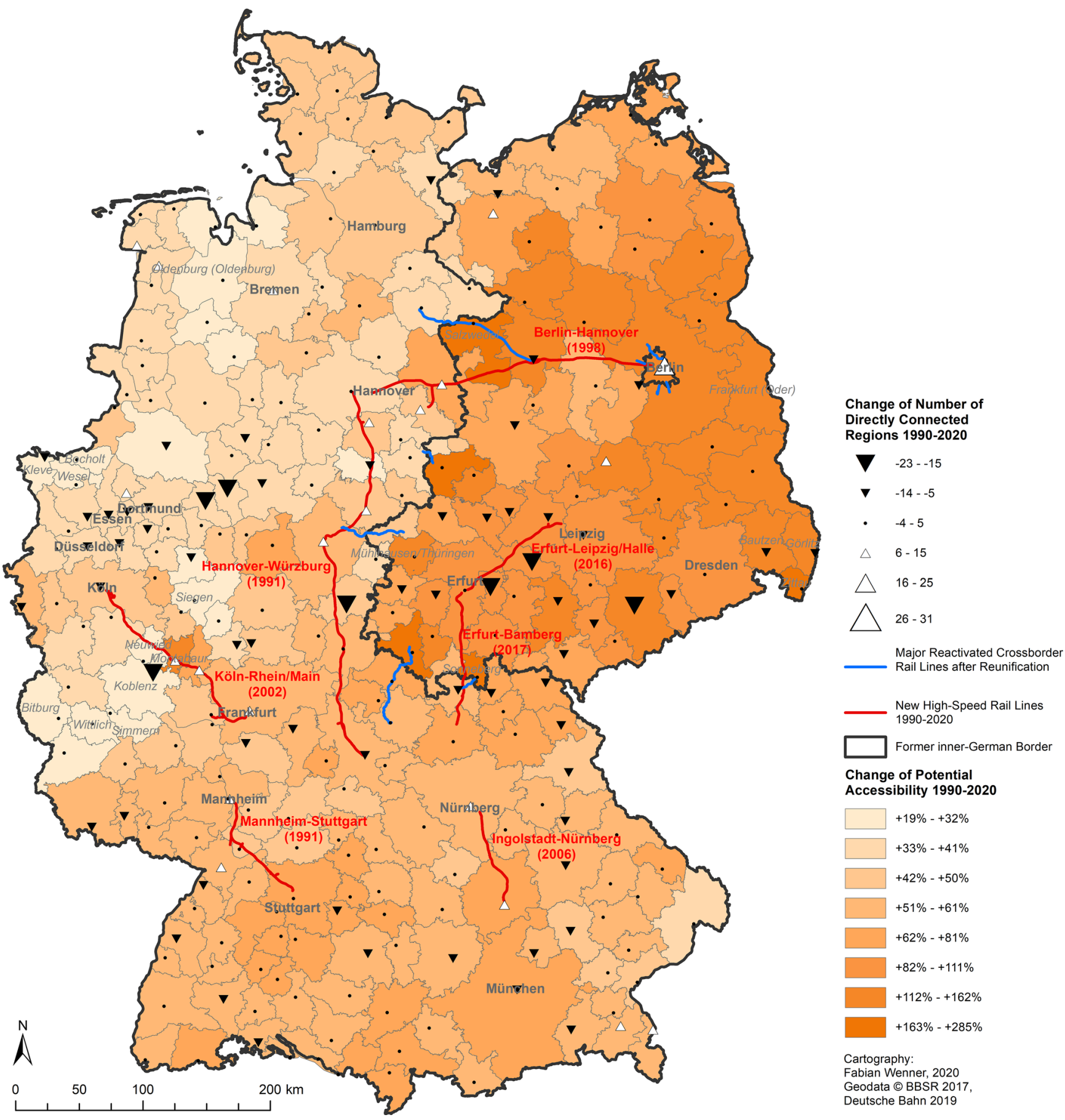

Figure 5 Change of Regional Rail Accessibility and Degree Centrality in Germany 1990-2020

\subsection{Increasing or Decreasing Accessibility Disparities?}

To show more clearly the winning and losing regions in relative terms, we consolidate the rail accessibility changes into a four-category matrix according to their previous standing and their accessibility change (Figure 6, cf. Stępniak/Rosik
2016: 9). Above average increases with a low baseline accessibility, which are instrumental for territorial cohesion, can be found in large parts of the eastern regions, particularly Erfurt, Leipzig, Dresden and Berlin, with their wider surroundings. Here, the effects of general infrastructure upgrade and high-speed rail complement each other, confirming Holzhauser and Steinbach (2000). Likewise, the below 


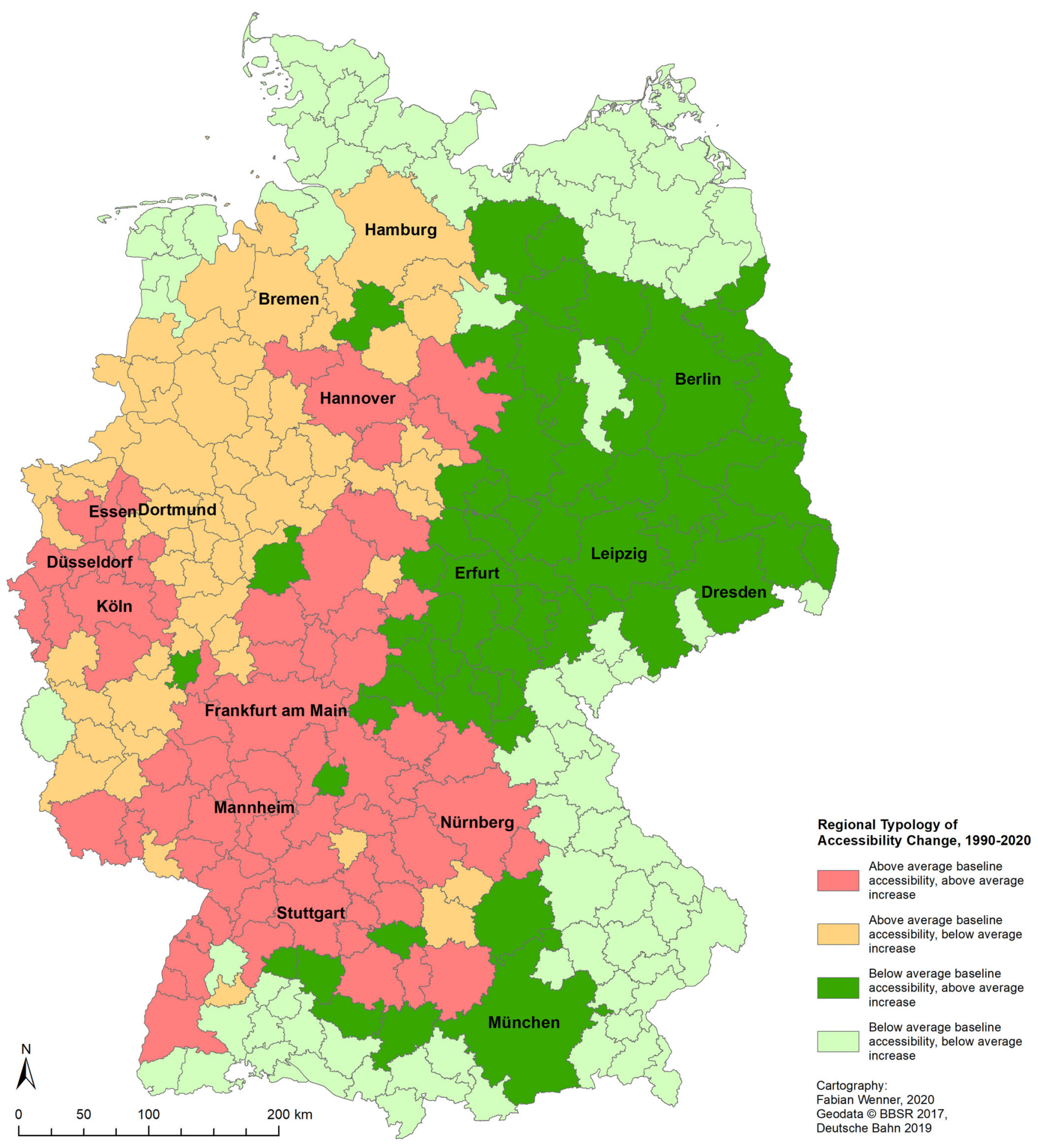

Figure 6 Typology of Regions by Accessibility Structure and Dynamics, 1990-2020

average increases in large parts of north-western Germany have a positive influence on cohesion, but show that constant accessibility levels can result in a relative loss of attractiveness. However, the figure also reveals a pattern of consolidation of high accessibility mostly in the south-west- ern regions that are already well endowed in terms of rail accessibility. This reflects the alignment and spatial pattern of high-speed rail investment in recent decades. Anti-cohesion effects can be furthermore observed in large parts of 


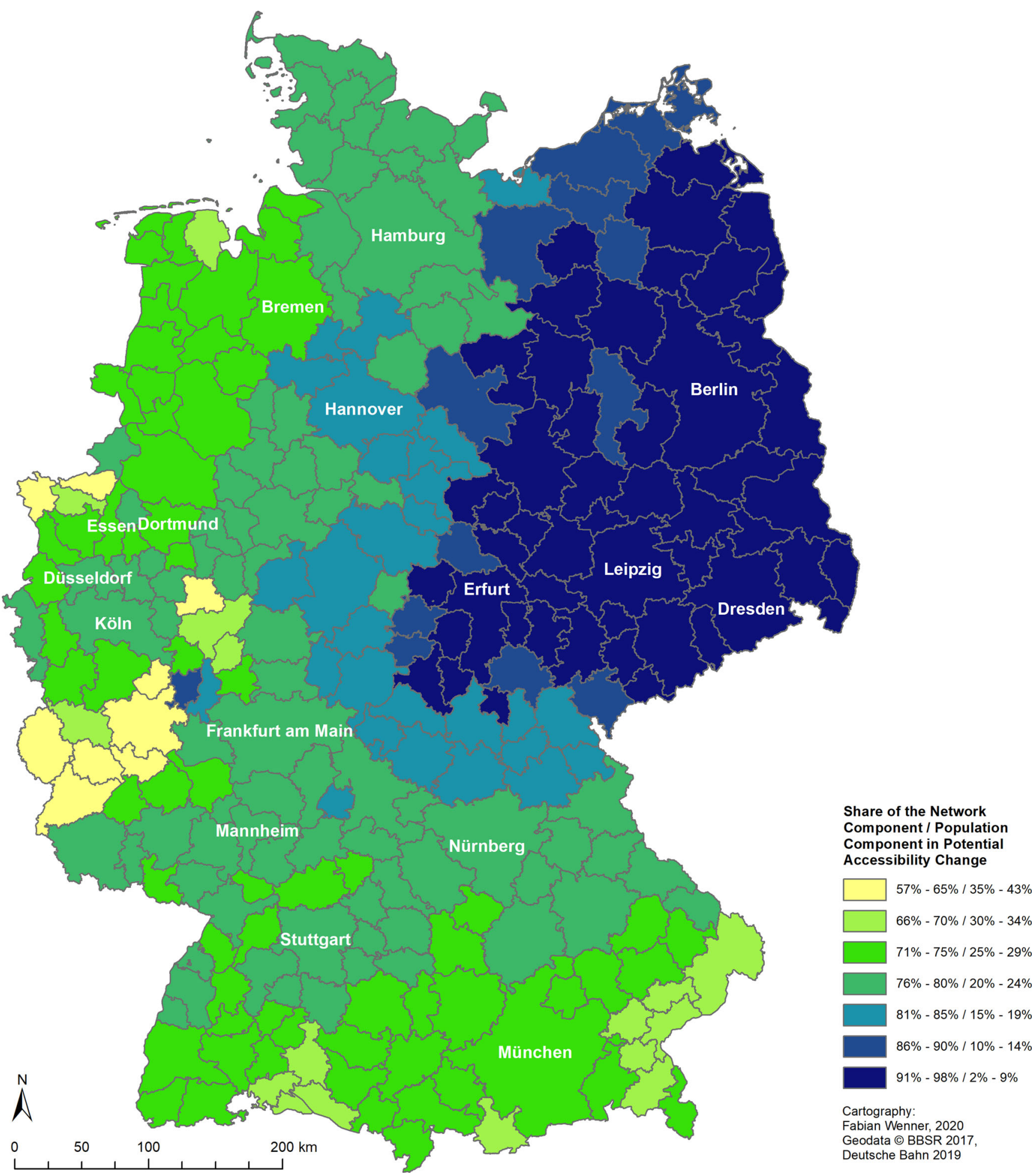

Figure 7 Share of the Network and Population Components in Potential Accessibility Change

the geographically peripheral areas in the north, southeast and south.

Next, we compare an alternative scenario with the rail network of 1990 but the population distribution of 2020 with the actual results, in order to differentiate between effects of rail infrastructure and population development (Figure 7). The share of population growth in accessibility increases varies between $2 \%$ and $43 \%$, the share of net- 


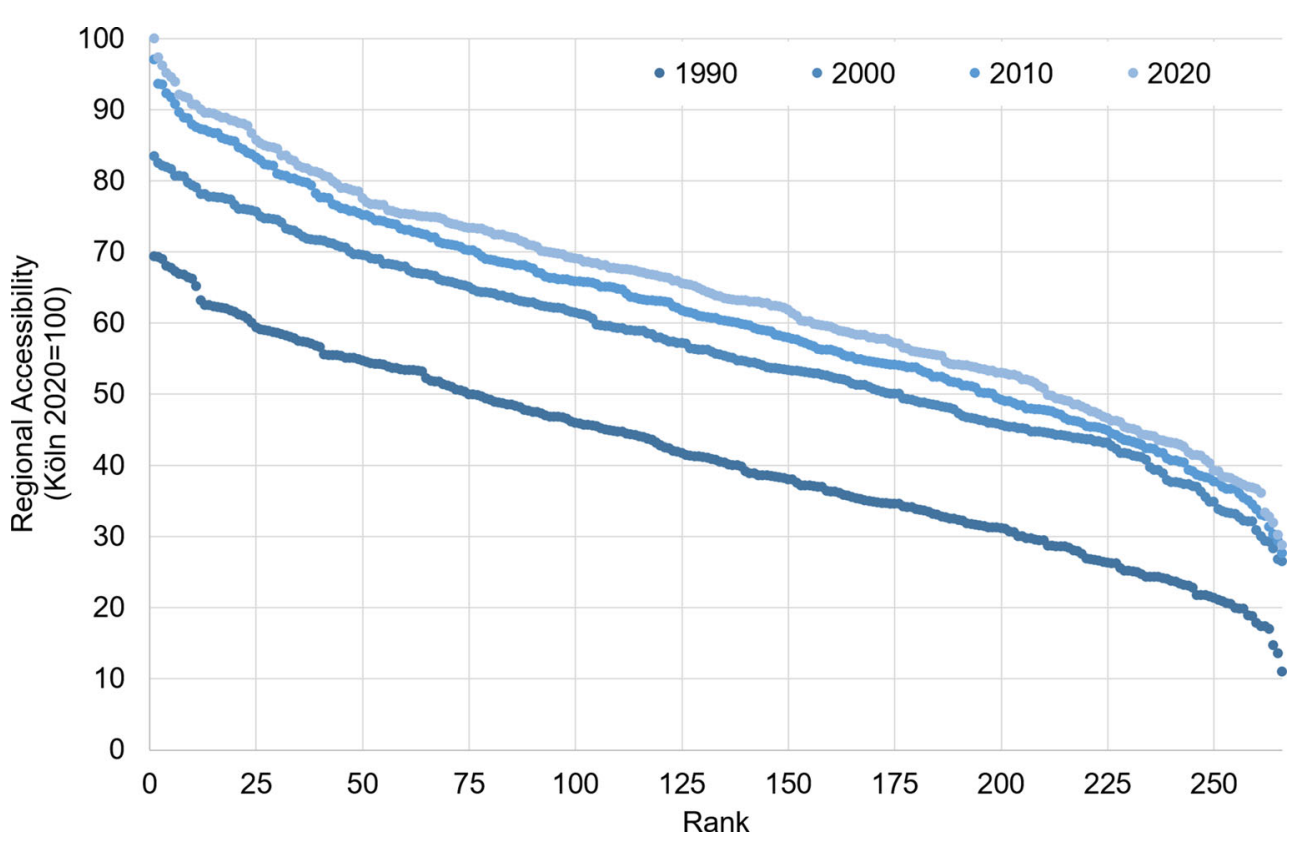

Figure 8 Distribution of regional rail accessibility in Germany by rank, 1990-2020

work effects between $57 \%$ and $98 \%$. After reunification in 1990, about 1.5 million people moved from the new to the old federal states. Nevertheless, it is surprising how clearly the former inner-German border can be identified. Accordingly, in eastern Germany, accessibility growth was almost completely due to network improvements. Had the network remained in its 1990 state, accessibility growth of peripheral eastern regions like Görlitz would have been minimal, mostly due to the far-reaching effects of population growth in Berlin and other urban areas that compensate local population losses. On the other hand, in some of the regions with the lowest overall accessibility growth, even this growth was mainly due to population increases. Rail investment has hence not followed population growth (as e.g. in Spain, Condeço-Melhorado/Zofío/Christidis 2017), but was deliberately concentrated on depopulating regions as structural aid, at least during the study period. This is also underlined by the fact that regions of the "disproportionately shrinking" and "shrinking" type in terms of population (following the classifications of the BBSR) have experienced significantly higher accessibility gains than other types in the 1990-2000 period, while in the later periods there is no clear difference between the types.

Sorting all regions by accessibility rank (Figure 8), one can observe an upward shift of the accessibility levels rather than a change of the slope, similar to the results of Axhausen, Fröhlich and Tschopp (2006: 18) for Switzerland, despite less growth at the lower end in recent decades. However, this level shift means that the least accessible regions now have a higher share than the most accessible regions. The shift is markedly stronger for the 1990-2000 period.
Persistent outliers can be found at both the upper and lower ends of the curve. While Spiekermann and Wegener (1996: 41) predicted an increasing Gini coefficient of rail accessibility and hence greater inequality on the European scale between 1993 and 2010, we find a decrease of the Gini coefficient of accessibility for German regions from 0.169 to 0.116 between 1990 and 2020. Likewise, the so-called Accessibility Dispersion (AD) index, sometimes used to evaluate the impacts of transport infrastructure development on territorial cohesion (Ortega/López/Monzón 2014: 18), decreases from 0.284 to 0.211 during the study period. Lower $\mathrm{AD}$ values indicate a more balanced distribution of accessibility. We find this cohesion effect to be mostly limited to the period of $1990-2000$ however, with only minimal changes afterwards. The Gini coefficient of degree centrality increases from 0.390 to 0.412 in the same timespan, confirming the observation of a greater concentration of direct interregional connections in metropolitan hubs.

\section{Conclusion and outlook}

This paper has reviewed previous studies of regional rail accessibility in Germany and complemented them by an analysis of changes in rail accessibility of 266 functional urban areas in Germany for four points in time: 1990, after German reunification and before the introduction of high-speed rail, 2000, 2010 and 2020. The study used a potential accessibility measure based on an exponential decay function calibrated for business trips, and a degree centrality measure for direct regional connections. The analysis confirms 
the general pattern of accessibility distribution with regions in the 'blue banana' of Europe exhibiting the highest accessibility levels. Regarding the dynamics, we find no evidence for growing rail accessibility disparities in Germany, despite the discontinuation of intermediate long-distance trains and the construction of high-speed rail infrastructure. Instead, there has been an accessibility increase across all regions throughout the study period. High-speed rail has led to extraordinary accessibility improvements in some cases, but the refurbishment of conventional rail lines and reopening of formerly dismantled cross-border lines in eastern Germany after 1990 have largely overshadowed the effects of high-speed rail, particularly in the first decade after reunification. Regarding degree centrality, we find a reduction of direct change-free connections between regions in favour of a concentration of long-distance lines on major metropolitan hubs.

High-speed rail effects in Germany have furthermore transcended the classical urban-periphery dichotomy and are spatially more extensive, but also more discretionary than in other European countries. This is due to the interlinkage of high-speed and conventional rail, the more dispersed settlement structure and piecemeal implementation of high-speed rail. Unlike in other countries, the most accessible region is not the capital city. We find a cohesive development of rail accessibility during the study period, which can however mostly be attributed to the first decade, 1990-2000, and has since come to a halt. Since then, both population development and the alignment of new highspeed rail lines have strengthened the accessibility of southern German regions.

The chosen approach has limitations. Particularly, the results might contrast with the local experience of rail line closures and discontinuation of services in the 1990s and 2000s. However, the study takes regions as spatial base units, which means that local lines within regions are not considered. Further improvements of the analysis should contrast the findings with accessibility for other modes, particularly road and air, also multi- and intermodally, and take generalised costs into account rather than pure time costs. Furthermore, recent studies have used a more timegeographical perspective and have highlighted the critical importance of certain time thresholds with regard to highspeed rail business trips (e.g. Chen/Hall 2011; Moyano/ Rivas/Coronado 2019). This perspective could be fruitful for further research regarding the German public transport system, as it is not yet considered widely in interregional transport. The analysis of betweenness centrality would likewise reveal changes in the importance of certain regions as hubs.

This paper has concentrated on travel times between regions as the main determinant of accessibility. For an inte- grated and seamless transport system, which is the policy goal of the current Federal Transport Infrastructure Plan and its "Deutschland-Takt", well-timed interchanges are more important than speed alone. Instead, 'sufficient' travel times between interchange nodes should guide infrastructure investment. A refinement of the methodology used here could take interchanges into account more explicitly.

Finally, it is interesting to reconsider that two of the first high-speed rail lines (Hannover-Würzburg, 1991; BerlinWolfsburg, 1998) were planned and partially constructed before German reunification, in a way that bypassed or transited East Germany. Transport infrastructure is costly, changes slowly and potentially has long-lasting implications on flows of people, goods and services. The accessibility maps shown in this paper would likely look different had reunification occurred earlier, pointing to the potential role of 'longue durée' (Braudel 1958; Wallerstein 1979) processes in regional economics.

Acknowledgements We thank the participants of the NECTAR Cluster 6 Accessibility Workshop in München in December 2019 for their most helpful comments and Diane Arvanitakis for proofreading. Any errors that remain are our sole responsibility.

\section{References}

Albalate, D.; Bel, G.; Fageda, X. (2012): Beyond the Efficiency-Equity Dilemma: Centralization as a Determinant of Government Investment in Infrastructure. In: Papers in Regional Science 91, 3, 599-615. https://doi.org/10. 1111/j.1435-5957.2011.00414.x

Andersson, M.; Karlsson, C. (2004): The Role of Accessibility for the Performance of Regional Innovation Systems. In: Karlsson, C.; Flensburg, P.; Hörte, S.-A. (eds.): Knowledge Spillovers and Knowledge Management. Cheltenham, 283-310.

Axhausen, K. (2008): Accessibility: Long-Term Perspectives. In: Journal of Transport and Land Use 1, 2, 5-22. https://doi.org/10.5198/jtlu.v1i2.66

Axhausen, K.W.; Fröhlich, P.; Tschopp, M. (2006): Changes in Swiss Accessibility since 1850 . Contribution to "Economic Impacts of Changing Accessibilities". Zürich. https://doi.org/10.3929/ethz-a-005226602

BAK Basel Economics (2007): Die Erreichbarkeit als Standortfaktor. Basel.

Banister, D.; Berechman, Y. (2001): Transport Investment and the Promotion of Economic Growth. In: Journal of Transport Geography 9, 3, 209-218. https://doi.org/10. 1016/S0966-6923(01)00013-8

Barthélemy, M. (2011): Spatial Networks. In: Physics Reports 499, 1-3, 1-101. https://doi.org/10.1016/j.physrep. 2010.11.002

BBSR - Bundesinstitut für Bau-, Stadt- und Raumforschung 
(2019): Methodische Weiterentwicklungen der Erreichbarkeitsanalysen des BBSR. Bonn. = BBSR-Online-Publikation 09/2019.

Berechman, J. (1995): Transport Infrastructure Investment and Economic Development. In: Banister, D. (ed.): Transport and Urban Development. Oxford, 17-35.

Beria, P.; Debernardi, A.; Ferrara, E. (2017): Measuring the Long-Distance Accessibility of Italian Cities. In: Journal of Transport Geography 62, 2017, 66-79. https:// doi.org 10.1016/j.jtrangeo.2017.05.006

Blum, U.; Haynes, K.E.; Karlsson, C. (1997): Introduction to the Special Issue the Regional and Urban Effects of High-Speed Trains. In: The Annals of Regional Science 31, 1, 1-20. https://doi.org/10.1007/s001680050036

BMVI - Bundesministerium für Verkehr und digitale Infrastruktur (2016): Bundesverkehrswegeplan 2030. Berlin.

Braudel, F. (1958): Histoire et Sciences Sociales: La Longue Durée. In: Annales. Economies, Sociétés, Civilisations 13, 4, 725-753.

Bruinsma, F.; Rietveld, P. (1993): Urban Agglomerations in European Infrastructure Networks. In: Urban Studies 30, 6, 919-934. https://doi.org/10.1080/ 00420989320080861

Bruinsma, F.; Rietveld, P. (1998): The Accessibility of European Cities: Theoretical Framework and Comparison of Approaches. In: Environment and Planning A: Economy and Space 30, 3, 499-521. https://doi.org/10.1068/ a300499

Brunet, R. (1989): Les Villes “Européennes”. Rapport Pour La DATAR. Montpellier.

Campos, J.; de Rus, G. (2009): Some Stylized Facts About High-Speed Rail: A Review of HSR Experiences around the World. In: Transport Policy 16, 1, 19-28. https://doi. org/10.1016/j.tranpol.2009.02.008

Cao, J.; Liu, X.C.; Wang, Y.; Li, Q. (2013): Accessibility Impacts of China's High-Speed Rail Network. In: Journal of Transport Geography 28, 12-21. https://doi.org10. 1016/j.jtrangeo.2012.10.008

Castells, M. (1996): The Information Age: Economy, Society and Culture. Cambridge.

Chen, C.-L.; Hall, P. (2011): The Impacts of High-Speed Trains on British Economic Geography: A Study of the UK's Intercity 125/225 and Its Effects. In: Journal of Transport Geography 19, 4, 689-704. https://doi.org/10. 1016/j.jtrangeo.2010.08.010

Chen, C.-L.; Hall, P. (2013): Using High Speed Two to Irrigate the Regions. In: Built Environment 39, 3, 355-368.

Clark, C. (1958): Transport: Maker and Breaker of Cities. In: The Town Planning Review 28, 4, 237-250. https:// doi.org/10.3828/tpr.28.4.kun370rn6pg882g3

Condeço-Melhorado, A.; Zofío, J.L.; Christidis, P. (2017): Drivers of Changes in Spanish Accessibility for the
1960-2010 Period. In: European Transport Research Review 9, 2, 19. https://doi.org/10.1007/s12544-017-02299

Erath, A.; Löchl, M.; Axhausen, K.W. (2009): Graph-Theoretical Analysis of the Swiss Road and Railway Networks over Time. In: Networks and Spatial Economics 9, 3, 379-400. https://doi.org/10.1007/s11067-008-9074-7

ESPON - European Spatial Planning Observation Network (2015): Tracc - Transport Accessibility at Regional/ Local Scale and Patterns in Europe. Final Report. Luxembourg.

European Council (1996): Council Directive 96/48/EC of 23 July 1996on the interoperability of the trans-European high-speed rail system. Brussels.

Evangelinos, C.; Hesse, C.; Püschel, R. (2011): Die Erreichbarkeit deutscher Großstädte durch den Schienenpersonenverkehr. In: ifo Dresden berichtet 18, 2, 20-27.

Florida, R. (2017): How Direct Flights Shape a City's Fortunes. https://www.citylab.com/equity/2017/10/ how-direct-flights-shape-a-citys-fortunes/544478/ (16.12.2020).

Freeman, L.C. (1979): Centrality in Social Networks. Conceptual Clarification. In: Social Networks 1, 3, 215-239. https://doi.org/10.1016/0378-8733(78)90021-7

Frost, M.E.; Spence, N.A. (1995): The Rediscovery of Accessibility and Economic Potential: The Critical Issue of Self-Potential. In: Environment and Planning A: Economy and Space 27, 11, 1833-1848. https://doi.org/10. 1068/a271833

Geertman, S.C.M.; Ritsema van Eck, J.R. (1995): GIS and Models of Accessibility Potential: An Application in Planning. In: International Journal of Geographical Information Systems 9, 1, 67-80. https://doi.org/10.1080/ 02693799508902025

Geurs, K.T.; van Wee, B. (2004): Accessibility Evaluation of Land-Use and Transport Strategies: Review and Research Directions. In: Journal of Transport Geography 12, 2, 127-140. https://doi.org/10.1016/j.jtrangeo.2003. 10.005

Gutierrez, J. (2001): Location, Economic Potential and Daily Accessibility: An Analysis of the Accessibliity Impact of the High-Speed Line Madrid-BarcelonaFrench Border. In: Journal of Transport Geography 9, 4, 229-242. https://doi.org/10.1016/S0966-6923(01)000175

Gutiérrez, J.; González, R.; Gómez, G. (1996): The European High-Speed Train Network: Predicted Effects on Accessibility Patterns. In: Journal of Transport Geography 4, 4, 227-238. https://doi.org/10.1016/S09666923(96)00033-6

Hall, P. (2009): Magic Carpets and Seamless Webs: Oppor- 
tunities and Constraints for High-Speed Trains in Europe. In: Built Environment 35, 1, 59-69.

Hall, P.; Pain, K. (2006): From Metropolis to Polyopolis. In: Hall, P.; Pain, K. (eds.): The Polycentric Metropolis. Learning from Mega-City Regions in Europe. London, 3-16.

Handy, S.L.; Niemeier, D.A. (1997): Measuring Accessibility: An Exploration of Issues and Alternatives. In: Environment and Planning A: Economy and Space 29, 7, 1175-1194. https://doi.org/10.1068/a291175

Hansen, W.G. (1959): How Accessibility Shapes Land Use. In: Journal of the American Institute of Planners 25, 2 , 73-76. https://doi.org/10.1080/01944365908978307

Harrer, B.; Scherr, S. (2013): Tagesreisen der Deutschen. Grundlagenuntersuchung. München.

Holzhauser, A.; Steinbach, J. (2000): Auswirkungen der „Verkehrsprojekte Deutsche Einheit“. In: Institut für Länderkunde (ed.): Nationalatlas Bundesrepublik Deutschland. Band 9: Verkehr und Kommunikation. Heidelberg, 128-131.

Jänsch, E. (1991): Hochgeschwindigkeitsverkehr auf Strecken der Deutschen Bundesbahn. In: Internationales Verkehrswesen 43, 9, 367-374.

Keeble, D.; Owens, P.L.; Thompson, C. (1982): Regional Accessibility and Economic Potential in the European Community. In: Regional Studies 16, 6, 419-432. https:// doi.org/10.1080/09595238200185421

Levinson, D.M.; Wu, H. (2020): Towards a General Theory of Access. In: Journal of Transport and Land Use 13, 1, 129-158. https://doi.org/10.5198/jtlu.2020.1660

Lutter, H.; Pütz, T. (1993): Erreichbarkeit und Raumentwicklung der Regionen in Europa. Welche Rolle spielen Fernverkehrssysteme? In: Informationen zur Raumentwicklung 9/10, 619-637.

Lutter, H.; Pütz, T.; Spangenberg, M. (1993): Lage und Erreichbarkeit der Regionen in der EG und der Einfluß der Fernverkehrssysteme. Bonn. = Forschungen zur Raumentwicklung 23.

Martín, J.C.; Reggiani, A. (2007): Recent Methodological Developments to Measure Spatial Interaction: Synthetic Accessibility Indices Applied to High-Speed Train Investments. In: Transport Reviews 27, 5, 551-571. https:// doi.org/10.1080/01441640701322610

Martínez Sánchez-Mateos, H.S.; Givoni, M. (2012): The Accessibility Impact of a New High-Speed Rail Line in the UK - a Preliminary Analysis of Winners and Losers. In: Journal of Transport Geography 25, 105-114. https:// doi.org/10.1016/j.jtrangeo.2011.09.004

Mohino, I.; Loukaitou-Sideris, A.; Urena, J.M. (2014): Impacts of High-Speed Rail on Metropolitan Integration: An Examination of London, Madrid and Paris. In: Inter- national Planning Studies 19, 3-4, 306-334. https://doi. org/10.1080/13563475.2014.950638

Monzon, A.; Lopez, E.; Ortega, E. (2019): Has HSR Improved Territorial Cohesion in Spain? An Accessibility Analysis of the First 25 Years: 1990-2015. In: European Planning Studies 27, 3, 513-532. https://doi.org/ 10.1080/09654313.2018.1562656

Moyano, A.; Rivas, A.; Coronado, J.M. (2019): Business and Tourism High-Speed Rail Same-Day Trips: Factors Influencing the Efficiency of High-Speed Rail Links for Spanish Cities. In: European Planning Studies 27, 3, 533-554. https://doi.org/10.1080/09654313.2018. 1562657

Münter, A.; Volgmann, K. (2014): The Metropolization and Regionalization of the Knowledge Economy in the Multi-Core Rhine-Ruhr Metropolitan Region. In: European Planning Studies 22, 12, 2542-2560. https://doi. org/10.1080/09654313.2013.844776

Östh, J.; Reggiani, A.; Galiazzo, G. (2014): Novel Methods for the Estimation of Cost-Distance Decay in Potential Accessibility Models. In: Condeço-Melhorado, A.; Reggiani, A.; Gutiérrez, J. (eds.): Accessibility and Spatial Interaction. Cheltenham, 15-37.

Ortega, E.; López, E.; Monzón, A. (2014): Territorial Cohesion Impacts of High-Speed Rail under Different Zoning Systems. In: Journal of Transport Geography 34, 16-24. https://doi.org/10.1016/j.jtrangeo.2013.10.018

Ottaviano, G. (2008): Infrastructure and Economic Geography: An Overview of Theory and Evidence. In: EIB Papers 13, 2, 8-35.

Plassard, F. (1994): High-Speed Transport and Regional Development. In: European Conference of Ministers of Transport (ed.): Regional Policy, Transport Networks and Communications. Paris, 33-83. https://doi.org/10.1787/ 19900228

Poelman, H.; Ackermans, L. (2016): Towards Regional and Urban Indicators on Rail Passenger Services, Using Timetable Information. Brussels. = Working Papers by the Directorate-General for Regional Policy 02/2016.

Ribalaygua, C.; Perez-Del-Caño, S. (2019): Assessing Spatial Planning Strategy in High-Speed Rail Station Areas in Spain (1992-2018): Towards a Sustainable Model. In: European Planning Studies 27, 3, 595-617. https://doi. org/10.1080/09654313.2018.1564189

Rosik, P.; Stępniak, M.; Komornicki, T. (2015): The Decade of the Big Push to Roads in Poland: Impact on Improvement in Accessibility and Territorial Cohesion from a Policy Perspective. In: Transport Policy 37, 134-146. https://doi.org/10.1016/j.tranpol.2014.10.007

Schliebe, K. (1983): Raumstrukturelle Wirkungen des Schienenschnellverkehrs in der Bundesrepublik Deutschland. In: Informationen zur Raumentwicklung 4, 213-230. 
Schliebe, K.; Würdemann, G. (1990): Peripherie und Zentren rücken dichter zusammen. Wie Das Großprojekt „Schienenschnellverkehr“ die Lageverhältnisse im Bundesgebiet ändert. In: Informationen zur Raumentwicklung 4-5, 223-244.

Schwarzer, C.; Treber, M. (2013): Emissionsminderung durch Hochgeschwindigkeitszüge. Bonn.

Seydack, N. (2015): Macht die Bahn hier bald das Licht aus? In: Die Zeit vom 16. Juli 2015. https://www.zeit. de/2015/29/jena-bahn-netz-anbindung-ice-fernverkehr (16.12.2020).

Song, S. (1996): Some Tests of Alternative Accessibility Measures: A Population Density Approach. In: Land Economics 72, 4, 474-482.

Spiekermann, K.; Neubauer, J. (2002): European Accessibility and Peripherality: Concepts, Models and Indicators. Stockholm. = Nordregio Working Paper 2002:9.

Spiekermann, K.; Wegener, M. (1996): Trans-European Networks and Unequal Accessibility in Europe. In: European Journal of Regional Development 4, 35-42.

Spiekermann, K.; Wegener, M. (2006): Accessibility and Spatial Development in Europe. In: Scienze Regionali 5, 2, 15-46.

Steinbach, J.; Zumkeller, D. (1992): Raumordnung und europäische Hochgeschwindigkeitsbahn. Schlußbericht. Stuttgart.

Stępniak, M.; Jacobs-Crisioni, C. (2017): Reducing the Uncertainty Induced by Spatial Aggregation in Accessibility and Spatial Interaction Applications. In: Journal of Transport Geography 61, Supplement C, 17-29. https:// doi.org/10.1016/j.jtrangeo.2017.04.001
Stępniak, M.; Rosik, P. (2016): From Improvements in Accessibility to the Impact on Territorial Cohesion: The Spatial Approach. In: Journal of Transport and Land Use 9, 3, 1-13. https://doi.org/10.5198/jtlu.2015.570

Stępniak, M.; Rosik, P. (2018): The Role of Transport and Population Components in Change in Accessibility: The Influence of the Distance Decay Parameter. In: Networks and Spatial Economics 18, 2, 291-312. https://doi.org/ 10.1007/s11067-017-9376-8

Thierstein, A.; Lüthi, S.; Kruse, C.; Gabi, S.; Glanzmann, L. (2008): Changing Value Chain of the Swiss Knowledge Economy. Spatial Impact of Intra-Firm and Inter-Firm Networks within the Emerging Mega-City Region of Northern Switzerland. In: Regional Studies 42, 8, 1113 1131. https://doi.org/10.1080/00343400802154557

Vickerman, R. (1997): High-Speed Rail in Europe: Experience and Issues for Future Development. In: Annals of Regional Science 31, 1, 21-38. https://doi.org/10.1007/ s001680050037

Wallerstein, I. (1979): The Capitalist World Economy. Cambridge.

Wenner, F.; Thierstein, A. (2020a): Results for Journal Article "Rail Accessibility in Germany: Changing Regional Disparities between 1990 and 2020". https://mediatum. ub.tum.de/1577251 (16.12.2020).

Wenner, F.; Thierstein, A. (2020b): Which Regions Benefit from New Rail Accessibility? Germany in 2030. In: disP - The Planning Review 56, 3, 59-76. https://doi.org/10. $1080 / 02513625.2020 .1851910$ 